University of Nebraska - Lincoln

DigitalCommons@University of Nebraska - Lincoln

USGS Staff -- Published Research

US Geological Survey

2016

Retrospective: Adjusting Contaminant Concentrations in Bird Eggs to Account for Moisture and Lipid Loss During Their Incubation

Barnett A. Rattner

U.S. Geological Survey, brattner@usgs.gov

Stanley N. Wiemeyer

St. Joseph, $M O$

Lawrence J. Blus

Beaverton, OR

Follow this and additional works at: http://digitalcommons.unl.edu/usgsstaffpub

Part of the Geology Commons, Oceanography and Atmospheric Sciences and Meteorology Commons, Other Earth Sciences Commons, and the Other Environmental Sciences Commons

Rattner, Barnett A.; Wiemeyer, Stanley N.; and Blus, Lawrence J., "Retrospective: Adjusting Contaminant Concentrations in Bird Eggs to Account for Moisture and Lipid Loss During Their Incubation" (2016). USGS Staff -- Published Research. 951.

http:// digitalcommons.unl.edu/usgsstaffpub/951

This Article is brought to you for free and open access by the US Geological Survey at DigitalCommons@University of Nebraska - Lincoln. It has been accepted for inclusion in USGS Staff -- Published Research by an authorized administrator of DigitalCommons@University of Nebraska - Lincoln. 


\title{
Retrospective: Adjusting Contaminant Concentrations in Bird Eggs to Account for Moisture and Lipid Loss During Their Incubation
}

\author{
Barnett A. Rattner ${ }^{1} \cdot$ Stanley N. Wiemeyer ${ }^{2} \cdot$ Lawrence J. Blus $^{3}$
}

Received: 14 March 2016/Accepted: 5 April 2016/Published online: 18 April 2016

(C) Springer Science+Business Media New York (outside the USA) 2016

This document is a U.S. government work and is not subject to copyright in the United States.
By the 1960s, research and monitoring efforts on chlorinated pesticide residues in tissues of wildlife were well underway in North America and Europe. Conservationists and natural resource managers were attempting to resolve whether pesticide exposure and accumulated residues were related to population declines in several species of predatory and scavenging birds (e.g., bald eagle Haliaeetus leucocephalus, peregrine falcon Falco peregrinus, brown pelican Pelecanus occidentalis and osprey Pandion haliaetus). The avian egg was a favored sampling matrix even before the realization that eggshell thinning was linked to population declines (Ratcliffe 1967; Hickey and Anderson 1968) and that the concentration of $p, p^{\prime}$-DDE in an egg was associated with the shell thinning phenomenon (e.g., Blus et al. 1972; Wiemeyer et al. 1988). The necessity for making wet-weight concentration adjustments to account for natural moisture loss during incubation of viable eggs was realized. Correction for the more dramatic moisture loss in non-viable decaying eggs was recognized as being paramount. For example, the $\sum$ DDT residues in osprey eggs were reported to vary by as much as eightfold without accounting for moisture loss adjustments (Stickel et al. 1965). In the absence of adjusting concentrations to the

Stanley N. Wiemeyer: Retired from U.S. Fish and Wildlife Service. Lawrence J. Blus: Retired from U.S. Geological Survey.

Barnett A. Rattner

brattner@usgs.gov

1 U.S. Geological Survey, Patuxent Wildlife Research Center, BARC-East, Buildling 308, 10300 Baltimore Avenue, Beltsville, MD 20705, USA

2 St. Joseph, MO 64504, USA

3 Beaverton, OR 97005, USA fresh wet-weight that was present at the time of egg laying, the uncorrected values exaggerated contaminant concentrations, yielding artifactual results and ultimately incorrect conclusions. The adjustment to fresh wet-weight concentration is equally important for many other persistent contaminants including PCBs, dioxins, furans, and brominated diphenyl ethers.

Lucille Stickel, Stan Wiemeyer and Larry Blus of the Patuxent Wildlife Research Center published "Pesticide Residues in Eggs of Wild Birds: Adjustment for Loss of Moisture and Lipid" in the Bulletin of Environmental Contamination and Toxicology in 1973 (vol. 9(4): 193-196). This wildlife toxicology citation classic describes the challenges of estimating the volume of egg contents, namely that water displacement of an intact egg includes the shell which affects volume estimates, and measurement of the inside volume of a blown egg prevents study of its embryo and is difficult to prepare when it contains a welldeveloped embryo. A series of equations were presented that used egg length and breadth measurements to derive egg volume for the bald eagle, brown pelican and osprey. Other methods of adjustment were mentioned, such as multiplying the volume of the egg by a factor slightly less than the specific gravity of the wet-weight contents to account for the air space, and adjusting to fresh lipid weight by determining a factor for lipid weight in relation to the volume of fresh eggs.

During this era, other papers appeared in the Bulletin documenting the significance of water loss when eggs were held at room temperature (McGinnis et al. 1976), and cautioning against the use of lipid weight for expressing pollutant levels in eggs unless the stage of incubation was known (Peakall and Gilman 1979). The "assumption" of no in ovo contaminant metabolism during incubation, which could significantly affect residue concentrations, 
was mentioned (Peakall and Gilman 1979). We have since learned that in ovo metabolism of xenobiotics affects the concentration of some compounds (e.g., petroleum hydrocarbons, Näf et al. 1992), but not others (e.g., PCBs, Custer et al. 2014). Hoyt (1979) suggested that the most accurate method to predict fresh egg weight was by refilling the air cell with water; the speed, accuracy and simplicity of this method was demonstrated some 30 years later (Heinz et al. 2009). The fresh weight of dehydrated eggs has also been estimated from an equation based on the length, breadth and fresh weight of eggs collected within 1 day of laying (Wiemeyer et al. 1986). While various methods of adjusting for moisture loss yield satisfactory results, the analytical errors associated with the contaminant residue estimates are much greater than those associated with correction for moisture loss (Heinz et al. 2009).

The paper by Stickel et al. (1973) is the 14th most frequently cited communication in the Bulletin (190 times in Google Scholar from 1975 to 2015, with an increased frequency of citation in the last decade). The papers that have cited it have dealt with at least 13 avian Orders, demonstrating the importance of expressing residue concentrations on a consistent basis among species. The moisture loss correction method has been taught in courses, and the citation has often appeared in standard operating procedures, lab manuals and unpublished reports. With the ongoing use of the avian egg in ecotoxicological monitoring and research studies, and renewed interest in standardization of egg collection and processing techniques (Klein et al. 2012), it is likely that this paper will continue to be highly cited for years to come.

Acknowledgments We thank Gary H. Heinz, Thomas W. Custer and an anonymous referee for their comments on a draft of this manuscript.

\section{References}

Blus LJ, Gish CD, Belisle AA, Prouty RM (1972) Logarithmic relationship of DDE residues to eggshell thinning. Nature 235:376-377
Custer CM, Custer TW, Thyen S, Becker PH (2014) Incubation stage and polychlorinated biphenyl (PCB) congener patterns in an altricial and precocial bird species. Environ Pollut 195:109-114

Heinz GH, Stebbins KR, Klimstra JD, Hoffman DJ (2009) A simplified method for correcting contaminant concentrations in eggs for moisture loss. Environ Toxicol Chem 28:1425-1428

Hickey JJ, Anderson DW (1968) Chlorinated hydrocarbons and eggshell changes in raptorial and fish-eating birds. Science 162:271-273

Hoyt DF (1979) Practical methods of estimating volume and fresh weight of bird eggs. Auk 96:73-77

Klein R, Bartel-Steinbach M, Koschorreck J, Paulus M, Tarricone K, Teubner D, Wagner G, Weimann T, Veith M (2012) Standardization of egg collection from aquatic birds for biomonitoring-a critical review. Environ Sci Technol 46:5273-5284

McGinnis CH Jr, Wallace LD, Burkhart DM (1976) Bobwhite quail eggs: some measurements and a method for estimating weight of egg contents. Bull Environ Contam Toxicol 15:497-503

Näf C, Broman D, Brunström B (1992) Distribution and metabolism of polycyclic aromatic hydrocarbons (PAHs) injected into eggs of chicken (Gallus domesticus) and common eider duck (Somateria molissima). Environ Toxicol Chem 11:1653-1660

Peakall DB, Gilman AP (1979) Limitations of expressing organochlorine levels in eggs on a lipid-weight basis. Bull Environ Contam Toxicol 23:287-290

Ratcliffe DA (1967) Decrease in eggshell weight in certain birds of prey. Nature 215:208-210

Stickel LF, Schmid FC, Reichel WL, Ames PL (1965) Ospreys in Connecticut and Maryland. Fish and wildlife service circular 226: effects of pesticides on fish and wildlife. 1964 Research Findings of the Fish and Wildlife Service, Washington, DC, pp 4-6

Stickel LF, Wiemeyer SN, Blus LJ (1973) Pesticide residues in eggs of wild birds: adjustment for loss of moisture and lipid. Bull Environ Contam Toxicol 9:193-196

Wiemeyer SN, Porter RD, Hensler GL, Maestrelli JR (1986) DDE, DDT + Dieldrin: residues in American kestrels and relations to reproduction. Fish and Wildlife Technical Report 6, Washington, DC

Wiemeyer SN, Bunck CM, Krynitsky AJ (1988) Organochlorine pesticides, polychlorinated biphenyls, and mercury in osprey eggs-1970-79 - and their relationships to shell thinning and productivity. Arch Environ Contam Toxicol 17:767-787 